\title{
Online Quiz Application for Informatics and Information System Students (Task Portal Development)
}

\author{
Maria Bellaniar Ismiati ${ }^{1 *}$, Latius Hermawan ${ }^{2}$ \\ ${ }^{1}$ Musi Charitas Catholic University, Bangau Street number 60, Palembang-30113, Indonesia \\ bella@ukmc.ac.id; ${ }^{1}$ tiuz.hermawan@ukmc.ac.id \\ corresponding Author*
}

\begin{tabular}{l} 
A R T I C L E I N F O \\
\hline Article History: \\
Receive January 1, 2020 \\
Received January 15, 2020 \\
Accepted February 10, 2020 \\
Available Online February 15, 2020 \\
\\
\hline Keywords: \\
E-Learning \\
Quiz \\
Internet
\end{tabular}

\section{Kata Kunci:}

E-Learning

Kuis

Internet

\section{Correspondence:}

Telephone: +62 (818) 02735717

E-mail: bella@ukmc.ac.id

\begin{abstract}
Internet technology is growing rapidly, not only in the business world but also in the world of education. The world of education is now widely using technological sophistication and internet-based, such as the process of teaching and learning electronically / known as e-learning. One of the features of e-learning in the teaching and learning process is that it can display material, practice questions, quiz, or exams electronically. During this time in UKMC, a quiz is often carried out in a conventional manner using paper that will multiply papers that are not used anymore. The purpose of this study is to create an online quiz application for Information Systems students so that lecturers and students can save time in the process and checking. Making an application can help conventional processes be developed by using technology and in real-time. The process of conducting this research starts from Requirements Planning, User Design, Construction, and Testing / Evaluation until finally, the final report is made. This research will present a Quiz menu with questions in the form of Multiple Choice, and there will be immediately the results of right and wrong answers along with grades and information on whether or not to pass. The results of this study are to reduce the paperless stack, and the interaction between students and lecturers is no longer conventional. This research is also a development of the task portal application for Informatics and Information Systems students that was made in the previous year.
\end{abstract}

\begin{tabular}{l} 
ABSTRAK \\
\hline Teknologi internet semakin berkembang pesat tidak hanya di dunia bisnis saja, tetapi \\
juga di dunia pendidikan. Dunia pendidikan sekarang sudah banyak yang menggunakan \\
kecanggihan teknologi dan berbasis internet, seperti proses belajar mengajar secara \\
elektronik / yang dikenal dengan e-learning. Salah satu fitur e-learning dalam proses \\
belajar mengajar adalah dapat menampilkan materi, soal latihan, kuis, ataupun ujian \\
secara elektronik. Selama ini di UKMC, kuis seringkali dilakukan dengan cara \\
konvensional yaitu menggunakan kertas yang akan memperbanyak kertas-kertas yang \\
tidak digunakan lagi. Tujuan penelitian ini adalah untuk membuat aplikasi quis online \\
bagi mahasiswa Sistem Informasi agar dosen dan mahasiswa dapat menghemat waktu \\
dalam pengerjaannya dan pengecekannya. Pembuatan aplikasi dapat membantu proses \\
konvensional dapat berkembang dengan menggunakan teknologi dan secara real time. \\
Proses pengerjaan penelitian ini dimulai dari Requirements Planning (Perencanaan \\
Persyaratan), User Design, Konstruksi, dan Testing / Evaluasi hingga yang terakhir \\
adalah pembuatan laporan akhir penelitian. Penelitian ini akan menampilkan suatu menu \\
Kuis dengan soal-soal berupa Pilihan Ganda dan nantinya akan langsung ada hasil \\
jawaban yang benar dan salah beserta nilai dan keterangan lulus atau tidaknya. Hasil \\
penelitian ini untuk mengurangi tumpukan kertas (paperless) serta interaksi antara \\
mahasiswa dan dosen tidak secara konvensional lagi. Penelitian ini juga merupakan \\
pengembangan dari aplikasi portal tugas bagi mahasiswa Informatika dan Sistem \\
Informasi yang telah dibuat di tahun sebelumnya.
\end{tabular}

\section{Introduction}

The world of education is experiencing very rapid development in the way of teaching. The way of teaching, in this case, includes interactive and interesting teaching using technology. The technology in question is based on multimedia and uses the internet network, for example, is through online systems or teaching through the internet network. The teaching process must also always be updated in the delivery of information, system functionality, and appearance. Teaching like this too has been done by 
many practitioners, both formal and non-formal education so that students can have more interest in the material presented. Therefore, the teaching process like this until now still has a positive role in the world of education.

The teaching methods referred to above, are generally known as electronic teaching methods or elearning. E-learning is a type of teaching and learning that allows the delivery of teaching materials to students using the Internet, Intranet or other computer network media [1]. The e-learning method is expected to help to teach and learning better and more effectively. Teaching is very helpful because by using an electronic learning system, the material will be better absorbed through exercises, quiz, even paperless online exams.

A quiz or exam is usually held as an evaluation material for the results of learning conducted in class for 1 semester of teaching and learning. Quizzes serve as material for teachers' feedback on the effectiveness of the learning process itself. With different objectives, the quiz/exam can also be meaningful as a test that can determine whether someone meets the standards set or fails to meet these standards. Along with the development of current technology, the manual examination system or often called conventional gradually wants to be changed into a system.

Based on the background and formulation of the problem above, a study was made with the title Online Quiz Application for Informatics and Information System Students (Task Portal Development). This research is a development from previous research, namely Task Portal Application For Informatics and Information System Students. The development is to add a menu in the application, which is a Quiz menu in which there are questions in the form of Multiple Choice. Multiple choice is used as a limitation in this study because when students finish completing all the multiple-choice questions, the quiz scores will immediately appear and the lecturer does not need to check one by one of the student answers that take a long time and can also reduce the stack of paper for conventional quizzes.

\subsection{Literature Review \\ 1.1.1 Application}

According to [2] Application software is a subclass of computer software that utilizes the ability of the computer directly to perform a task the user wants. Usually compared to system software that integrates a variety of computer capabilities, but does not directly apply that ability to do a task that benefits the user. The main examples of application software are word processors, worksheets, and media players. Some applications that are joined together into a package are sometimes referred to as a package or application suite (application suite). An example is Microsoft Office and Open Office.org, which combines a word processing application, a worksheet, and several other applications. The applications in a package usually have a user interface that has similarities making it easier for users to learn and use each application. Often, these applications can interact with each other so that it benefits the user.

\subsubsection{Quiz}

Quizzes can add insight and enhance students' abilities about the subject matter that is being learned. Quizzes can also stimulate students to learn. [3] said that the use of technology in the learning process will cause excitement because students interact with images, videos, and animations. This condition of pleasure is an important factor in learning effectiveness. Besides that various kind of activities such as analysis, drawing, visualisation and exploration can be carried out using applications such as multimedia, quiz creator and so on.

\subsubsection{Website}

Understanding the website is an internet facility that connects documents in a local or long-distance scope. Documents on the website are called web pages and links on the website allow users to move from one page to another (hypertext), both between pages stored on the same server and servers around the world [4].

\subsubsection{PHP and MySQL}

PHP (Hypertext Preprocessor) is a main server-side script language that is inserted into HTML that is run on the server and can also be used to create desktop applications. According to Betha Sidik, in his book entitled Web Programming with PHP [5], states that: "PHP is generally known as programming 
languages scripts that create HTML documents on the fly that are executed on web servers, HTML documents generated from an application not an HTML document created using a text editor or HTML editor, also known as a server-side programming language". MySQL is database software. MySQL is a relational data type which means MySQL stores its data in the form of interconnected tables. The advantage of storing data in a database is its convenience in storing and displaying data because it is in the form of a table [6].

\subsubsection{Rapid application development (RAD)}

Rapid application development (RAD) or rapid prototyping is a model of software development processes classified as incremental (multilevel) engineering. RAD emphasises short, short and fast development cycles. Short time is an important limitation of this model. Rapid application development uses an iterative method in developing systems where the working model of the system is constructed at the beginning of the development phase to establish user requirements and subsequently removed [6].

\subsubsection{Prior Research}

[7] in a study that aims to create an online exam system model design for students in a school to get the following results: online test system software that is made able to provide a database of questions, both UAN questions and special questions provided by UN subject teachers based on SKL (graduate competency standard). These questions can be accessed by students using the internet network during school hours or outside school hours. Questions are equipped with answer keys and how to solve problems.

[8] in his research entitled Making Online Examination System Application at SMK Garuda Nusantara Bekasi get the results that this application can help solve problems for school management in improving the effectiveness of teaching and learning and online value management with internet technology. Also, it can reduce operational costs and make it easy for students and teachers to assess without having to record grades with a book.

[9] in her research entitled Website-Based Online Exam System has succeeded in getting the results that the implementation of the website-based online exam system created generates positive responses from users, in this case, STMIK STIKOM Indonesia students. This is indicated by the outline of the questionnaire results agreeing to the existence of the application and the good quality of the application.

\section{Method}

\subsection{Software Development Model}

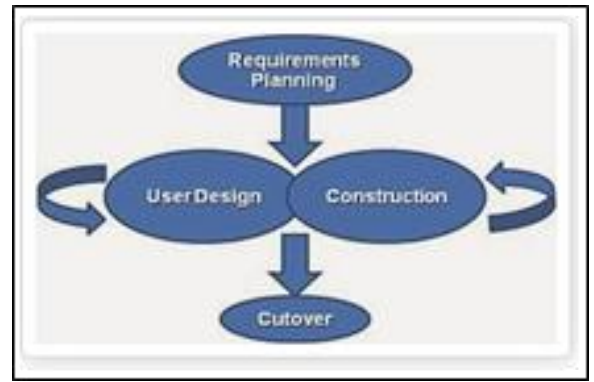

Fig. 1.Rapid Application Development [7]

The RAD phase consists of 4 phases, namely:

1. Requirements Planning

At this stage, users (students) and analysts (researchers) conduct a kind of meeting to identify the purpose of the application or system and identify the information needs to achieve the goal.

\section{User Design}

At this stage is to carry out the design process and make improvements if there are still design mismatches between the user and the analyst. For this stage, the activeness of the user involved is crucial to achieving the goal, because the user can directly comment if there is a mismatch in the design. The most important thing is that user involvement is needed so that the system developed can provide 
satisfaction to the user and in addition, the old system does not need to be run in parallel with the new system.

\section{Constructions}

The constructions step aims to build the system based on the modeling design results that have been obtained. Based on the results of the modeling design, construction is carried out in the form of coding or codification of the program. Codification is the process of writing source code or source code that will build the system in terms of system interfaces and logic or the process of the system itself. The source codes used in this codification stage include HTML source code as a system interface design, and PHP source code as a programming language that forms the logic or process of the system.

\section{Cutover}

The last step taken is the cutover stage. This stage resembles the final task in the SDLC implementation phase, including data conversion, testing online quiz applications to users and training users in using the online quiz application.

\subsection{Five Stages of Research}

Overall, research activities will be divided into five stages of research. The following is a brief description of each stage of research.

\section{Stage I}

At this stage a deeper identification of needs will be carried out. The expected outcome of this stage is a list of identification, both functional and non-functional needs. At this stage the researcher delves deeper into the application of the task portal that has been made in previous research about what can be added so that this system can become a complete e-learning. In this system, menus and processes for uploading and downloading assignments are given by lecturers. Furthermore, to develop this system into e-learning, researchers added a menu for exam questions that contained online quizzes to complete the task portals that had been made. This stage enters the requirements planning stage in RAD.

\section{Stage II}

Based on the identification of needs that have been made, at this stage an analysis of software will be built. The results of the analysis are modelling software that is ready to be designed. In this study, the result of the analysis is the creation of a menu of exam questions which are combined into one in the task portal application. The contents of the menu of this exam are select class, dashboard, manage questions, test results, test settings, user list, main homepage. All menus are made to support the online quiz in order to help lecturers and students for paperless. This stage is entered into the user design stage in RAD.

\section{Stage III}

The software model that was created in phase II will be translated into software design that is ready to be coded with the programming languages HTML, CSS, PHP MySQL, Javascript. After all the menu interfaces and application logic flow are finished, the programmer will start working to enter the coding phase of the program. This software is based on a website so that it can be accessed online and in realtime. This stage is entered into the constructions stage in RAD.

\section{Stage IV}

At this stage, the software coding will be done. The programmer starts working at this stage by using the guidance from stages 1-3 which have been explained above. The result of this activity is website based software. This stage is entered into the constructions stage in RAD.

\section{Stage V}

At this stage, application testing will be done directly to the user of the website that has been created. This test is when students work on the online quiz in real-time. After finishing the work, a check is made whether the results that come out are appropriate. That can display the number of students who graduated and did not so as to facilitate lecturers in the assessment. This stage is entered into the cutover stage in RAD. 


\section{Results and Discussion}

\subsection{Initial view of the Task Portal}

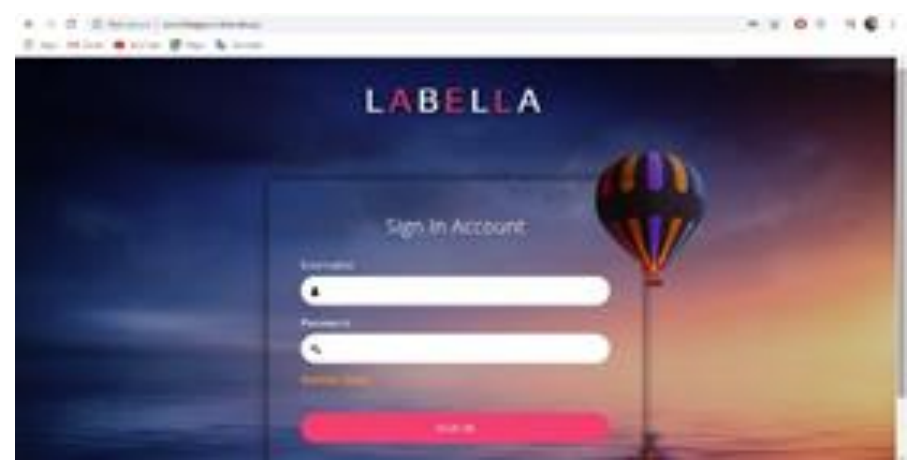

Fig. 2. Task Portal Application Login Page

This page is the initial login page to enter the online task and quiz portal application. Access rights in this application are admin (lecturer) and end user (student). If the lecturer and student do not have an account, the lecturer and student must enter the register link here. After having an account, you can directly enter the account into the username and password section. After students register, the lecturer must first activate the account so that the student can then log in by entering the activated username and password.

\subsection{Initial display of the Task Portal}

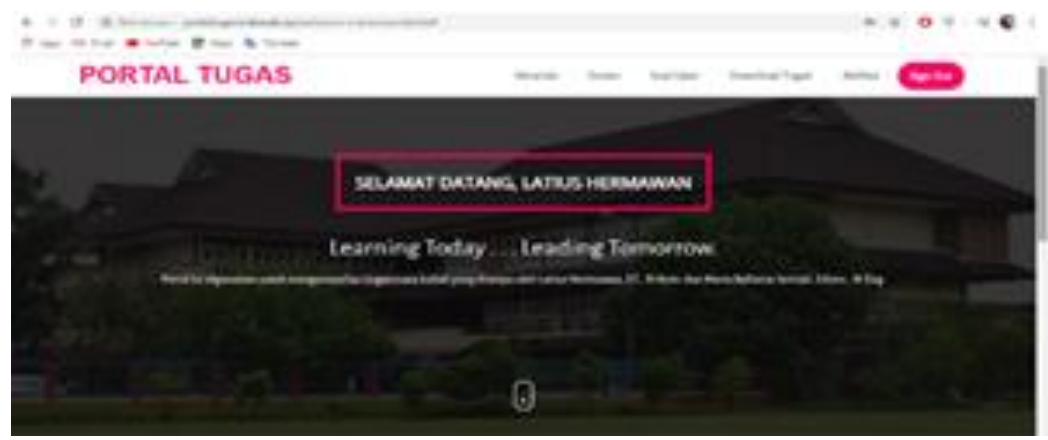

Fig. 3. Homepage of Task Portal

This display is the initial display when the lecturer successfully enters the task portal application. In some of the menus provided, there are Exam Question menus which are menus for online quizzes that must be done by students.

\subsection{Display Select Class}

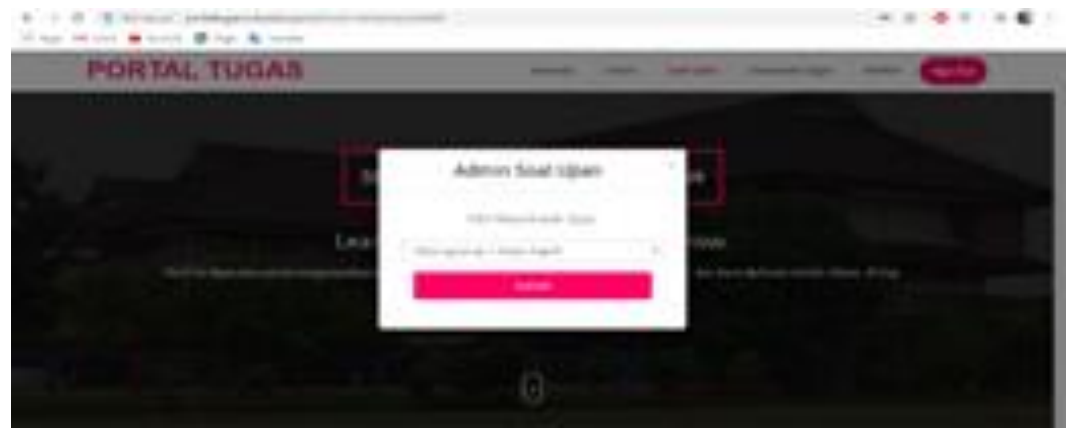

Fig. 4. Display Select Subject 
This page is for selecting courses to take the quiz. After the lecturer has finished selecting one of the courses, then click the submit button to enter the quiz section and menus in the online quiz.

\subsection{Display of Manage Questions Menu}

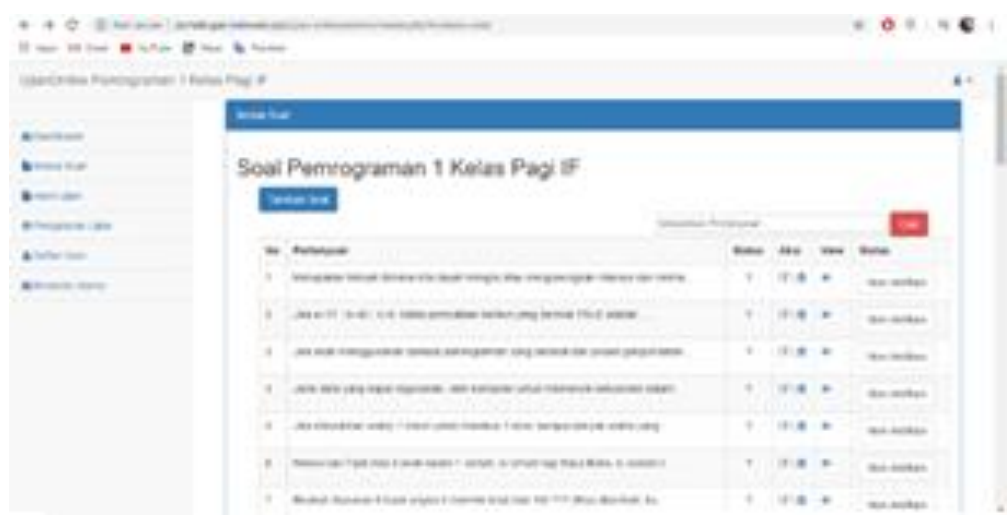

Fig. 5. Display Menu to Manage Quiz Questions

On this menu, there are menus to add questions, a list of questions, action buttons to edit and delete questions, the view section to see the answer key, and the status of the problem. In this menu, the lecturer can search for questions that have been made using a keyword.

\subsection{Display Add Questions}

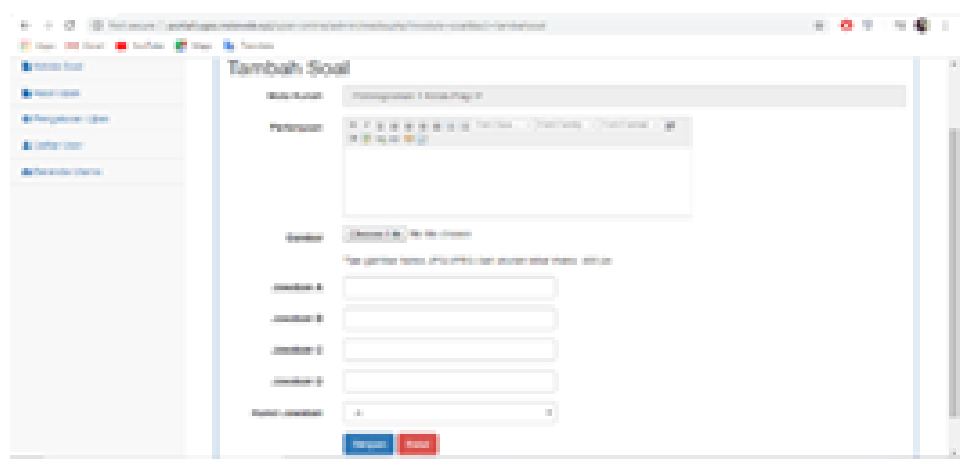

Fig. 6. Display Add Questions

In this menu, the lecturer can enter questions, pictures, all answers from A-D along with the Answer Key for each question. After the lecturer completes the questions and answers, the lecturer must click the save button so the questions can appear in the online quiz.

3.6 Display the Exam Results in Menu

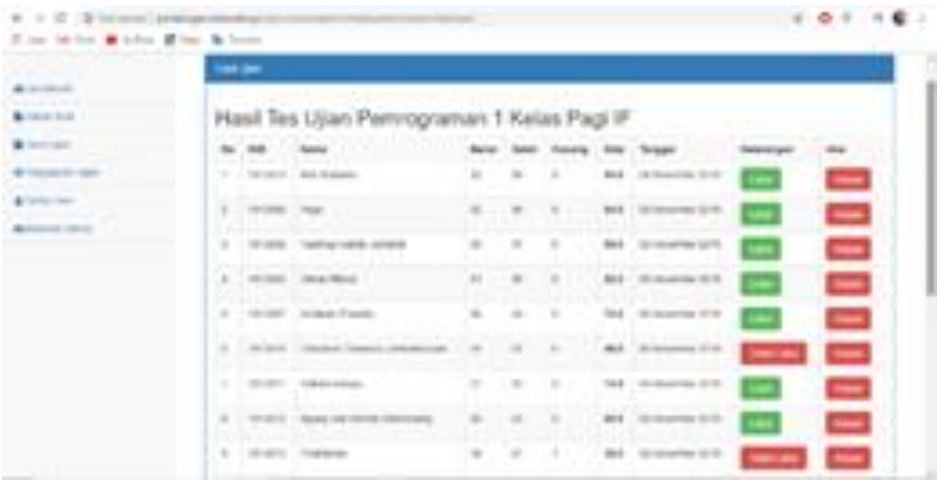

Fig. 7. Display the Exam Results in Menu 
In this view, the lecturer can immediately see who the students who passed and did not pass along with the test results for the quiz in the course. There is also several right and wrong for each student who has taken the quiz. Also, it can also be known on what date the quiz was held.

\subsection{Display the Exam Settings Menu}

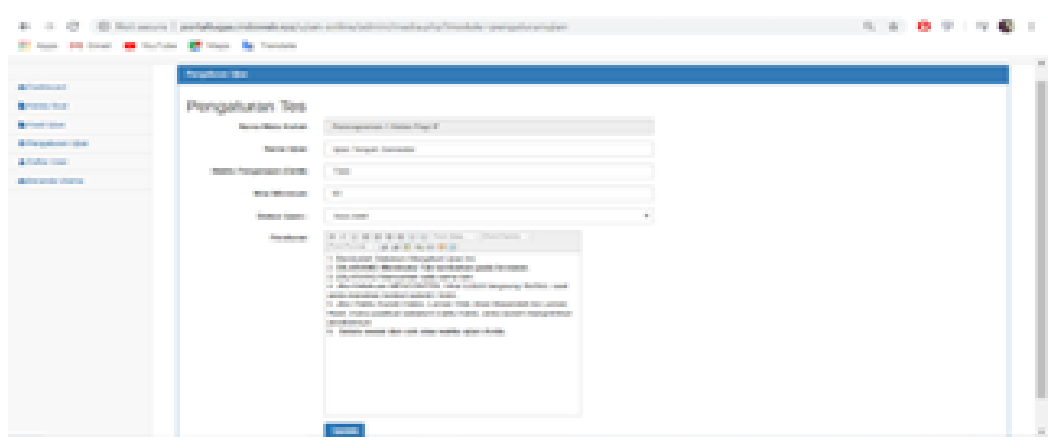

Fig. 8. Display of the Exam Settings Menu

In this menu, the lecturer can enter information about the deadline for the work, the minimum score, the status of the exam, and regulations. When the working time is over, then all student answers are automatically saved and will pass or not pass for each student. Lecturers can also set a minimum grade for graduation in one subject. The regulations made can be adjusted for each lecturer who is in charge of the subject matter concerned. After all the information has been entered, the lecturer must click the update button to display all the information when the quiz is held.

\subsection{Display User List Menu}

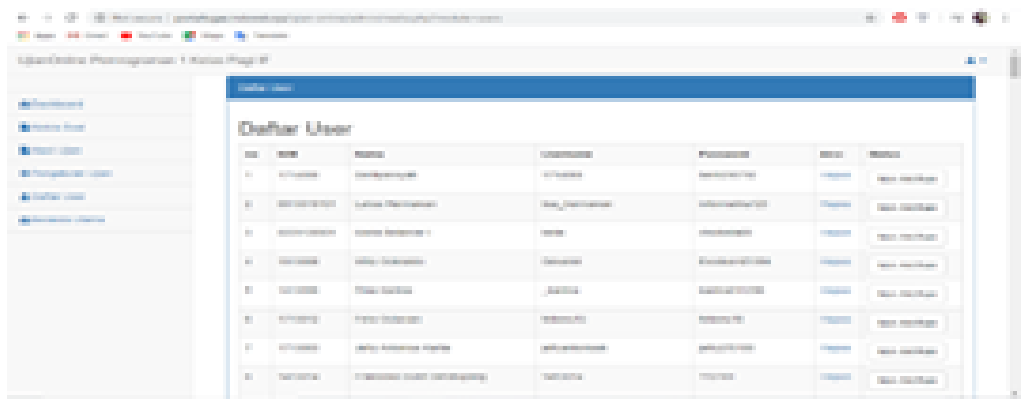

Fig. 9. Display User List Menu

The above page is a display of all the list of users who have registered for this task portal application. If there are students who are not active, then the student status can be deactivated through the status section.

\subsection{Display of the Student start page}

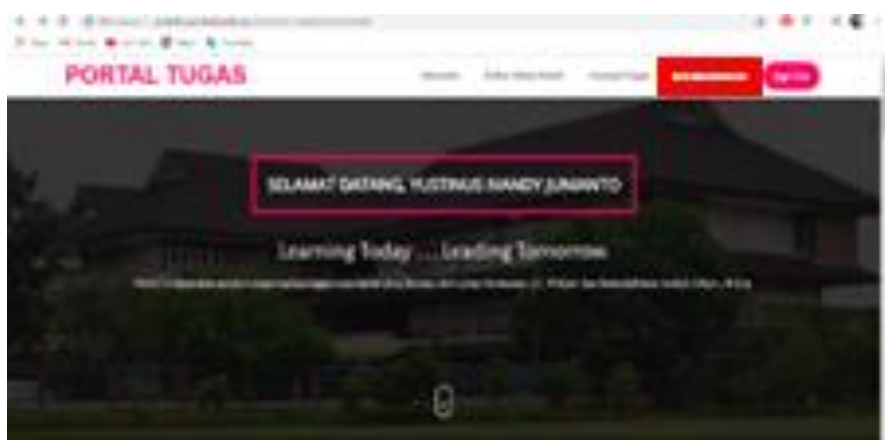

Fig. 10. Display of the start page of students 
This display is the initial display when students successfully enter the task portal application. In some of the menus provided, there is a Student Examination menu which is a menu for online quizzes that must be done by students.

\subsection{Dashboard Menu view}

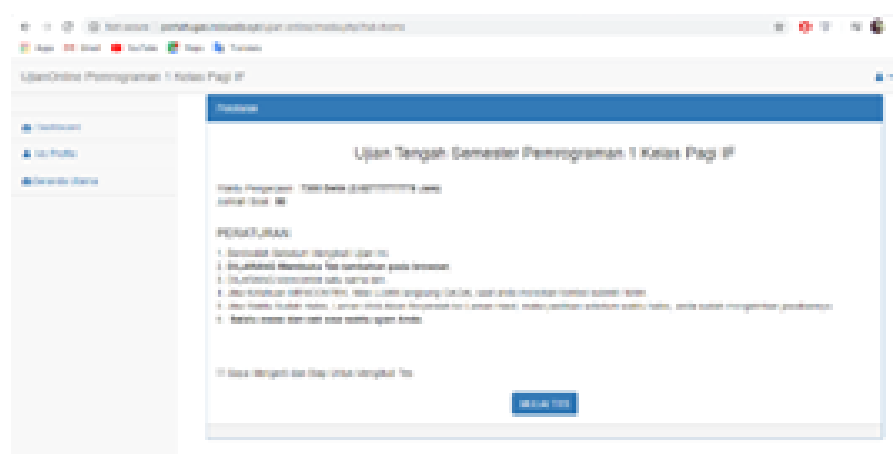

Fig. 11. Display Dashboard Menu

This page is the page before students work on quiz questions that have been made by professors. Students must read carefully what are the rules set by the lecturer and students must also check the small box next to the writing I understand and are ready to take the test before pressing the start test button.

\subsection{Display of Quiz Questions}

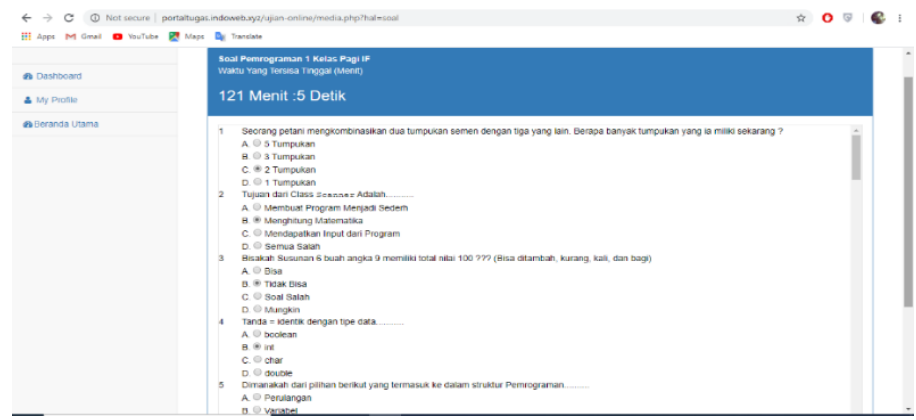

Fig. 12. Quiz Problem Display

The above display is a display when students have clicked the start test button. The time allotted appears at the top represented by minutes and seconds. Students can directly click on one of the answers between A to $\mathrm{D}$ for the correct answer according to the student. All questions are displayed on one page and can be scrolled down. After students are confident about the answers given, then at the bottom there is a submit answer button. When finished, click the button, a page will appear as shown in Figure 12.

\subsection{Display Complete Quiz Work}

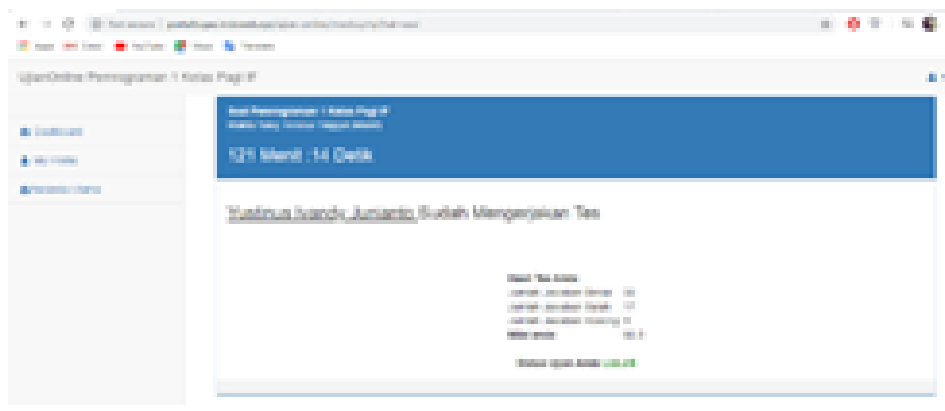

Fig. 13. Display Completed Quiz Work 
The above page is a display when students finish working on a quiz in one of the courses. In the display, there is information about the number of rights, wrong, and blank answers. In addition, there are also scores obtained and exam status for a student.

\subsection{Display of Test Question Dashboard Menu (Lecturer)}

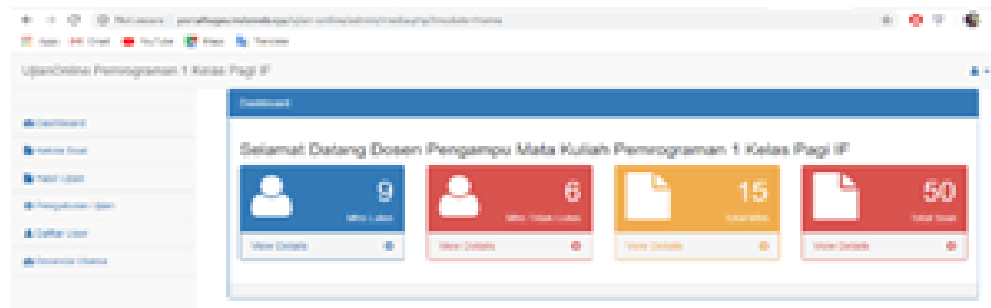

Fig. 14. Display Dashboard Exam Question Menu (Lecturer)

The above display can be information for lecturers regarding the number of students graduating and not graduating from the total number of students. In addition, it can also be known the number of questions made for the course concerned.

\subsection{Blackbox Testing}

Table 1. Blackbox Testing

\begin{tabular}{|c|c|c|c|c|}
\hline No & Process & Information & Consistent & Inconsistent \\
\hline 1 & Lecturer Login & $\begin{array}{l}\text { After the lecturer enters the username and password correctly } \\
\text { it will go to the lecturer assignment start page }\end{array}$ & $\sqrt{ }$ & \\
\hline 2 & Add quiz questions & $\begin{array}{l}\text { After the lecturer enters the question, the answer choices and } \\
\text { the answer key and saved, the question will appear on the } \\
\text { student quiz page }\end{array}$ & $\sqrt{ }$ & \\
\hline 3 & Quiz Settings & $\begin{array}{l}\text { After the lecturer enters all quiz rules and updates, the rules } \\
\text { will appear on the student dashboard }\end{array}$ & $\sqrt{ }$ & \\
\hline 4 & Student login & $\begin{array}{l}\text { After students enter their username and password correctly } \\
\text { they will enter the start page of the student assignment portal }\end{array}$ & $\sqrt{ }$ & \\
\hline 5 & Quiz & $\begin{array}{l}\text { After students answer all quiz questions according to the } \\
\text { specified time and submit, the quiz results appear in the form } \\
\text { of the number of correct, incorrect, blank answers, quiz } \\
\text { grades and pass / no status. }\end{array}$ & $\sqrt{ }$ & \\
\hline 6 & $\begin{array}{l}\text { Lecturer } \\
\text { Dashboard }\end{array}$ & $\begin{array}{l}\text { After students answer all quiz questions according to the } \\
\text { specified time and submit, the lecturer dashboard shows the } \\
\text { number of students graduating, not graduating, total students, } \\
\text { and total questions }\end{array}$ & $\sqrt{ }$ & \\
\hline
\end{tabular}

\section{Conclusion}

From the online quiz application that has been made, the results obtained are that this application can function as it should be able to do online and real-time quizzes and can display information on grades and information on whether or not students are working on the online quiz. This online quiz is also made to complete the task portal application that has been made in previous research.

\section{Acknowledgement}

The authors thank the Musi Charitas Catholic University for the opportunity given to complete internal research. Internal research has mandatory outcomes, namely, the Journal. also, the author also did not forget to thank all parties involved in this research. Hopefully, in the future, the writer can continue to make research that is useful for students, lecturers, and other fellow writers.

\section{References}

[1] Hartley, Darin E. 2001. Selling E-Learning, American Society for Training and Development.

[2] Nazruddin Safaat H. 2012 (Edisi Revisi). Pemograman Aplikasi Mobile Smartphone dan Tablet PC Berbasis Android. Informatika. Bandung. 
[3] Suryadi, D. 2007. Pendidikan Matematika. Dalam Ali, M., Ibrahim, R., Sukmadinata, N.S., Sudjana, D., Rasjidi, W. (Penyunting). Ilmu dan Aplikasi Pendidikan. Bandung:Pedagogiana Press.

[4] Fatta, Al Hanif. 2007. Analisis \& Perancangan Sistem Informasi, Yogyakarta : Penerbit ANDI.

[5] Betha Sidik. 2012. Pemrograman Web dengan PHP. Informatika,. Bandung.

[6] Winarno, Edy; Ali Zaki, SmithDev. 2014. "Pemrograman Web Berbasis HTML5, PHP, dan JavaScript". Jakarta: PT Elex Media Komputindo

[7] Britton, Carol (2001). Object-Oriented Systems Development. McGraw-Hill. hlm. 28-29, 269. ISBN 0-07709544-8.I.S. Jacobs and C.P. Bean, "Fine particles, thin films and exchange anisotropy," in Magnetism, vol. III, G.T. Rado and H. Suhl, Eds. New York: Academic, 1963, pp. 271-350.

[8] Fahmi, Amiq. 2011. Desain Model Sistem Ujian Online. Seminar Nasional Teknologi Informasi \& Komunikasi Terapan 2011 (Semantik 2011). Semarang.

[9] Riyadi, Ahmad. 2019. Pembuatan Aplikasi Sistem Ujian Online Pada SMK Garuda Nusantara Bekasi. Jurnal Ilmiah Sinus (JIS) Vol : 17, No.1, Januari. Jakarta.

[10] Saraswati, Ni Wayan Sumartini, dkk. 2015. Sistem Ujian Online Berbasis Website. Jurnal S@CIES Volume 6, Nomor 1, Oktober 2015. Bali. 